\section{The Pace of Progress}

Is his Rede lecture at Cambridge on March 4, Sir Daniel Hall discussed the way in which State control is tending to retard the rate of material progress based upon science, and the effect of this tendency on scientific life and thought. From the re-birth of science at the Renaissance, the time-span of social and technical progress has steadily diminished. The two centuries between the invention of printing and the foundation of the Royal Society; the hundred and forty years from that time to the close of the eighteenth century; the first ninety years of the nineteenth century; and the last forty years can be regarded as a series of diminishing time-spans of approximately equal material advance. Material progress which formerly was spread over several generations now occurs within a single lifetime, and our social economy is correspondingly disturbed. This disturbance is the greater because of the persistence of a social structure developed when agriculture was the dominant as well as the primary industry of mankind. Agriculture is at present the outstanding example of an industry brought to an economic standstill because of our inability to handle the enhanced powers of production due to science. The theory of over-production, however, postulates a static society and an inelastic demand, and the disturbing effect of science in the form of invention and discovery is enhanced by greater efficiency, made possible through advances in the technique of organisation.

Sir Daniel Hall suggested that the difficulty of adjusting the pace of increased production to the social structure first became apparent in agriculture, and that the failure of peasant farming to stand up to the competition of mechanised farming in America and the newer countries was the fundamental factor in determining the shift of fiscal policies in Europe from 1870 onwards. The initial aim of these policies in Europe was to preserve the fundamental peasant basis of each State and to check the rate of material change. The policy of national self-sufficiency pursued by such different methods, for example, as in the Irish Free State and in Italy or Germany, has essentiaily the same object, and commences by lowering the standard of living as the inevitable consequence of excluding imported goods. In contrast to countries which are content to forego material advantages promised by scientific progress and to accept a low standard of living as the price of national unity and sufficiency, the equally isolated Russian State embraces science as the means of creating real wealth which can be shared among all its population and definitely seeks to raise the standard of living. This system also presupposes a closed autocracy in which it is doubtful whether science can continue to grow or be required, and Sir Daniel suggests that the Marketing Boards now being tried in Great Britain, while an alternative to these two types of autocracy, equally eliminate individual enterprise and threaten to damp the fire of research. Science is an extinguishable response to man's inherent curiosity and its course needs to be broadened not arrested, so that science serves the majority and not merely the interests of a few.

\section{Scientific Developments and Defence Against Air Attacks}

ThE Under-Secretary of State for Air, Sir Philip Sassoon, announced in the House of Commons recently that a special committee has been set up to investigate the possibilities of countering air attacks by utilising recent progress in scientific invention. The committee, which is already at work, consists of Mr. H. T. Tizard, rector of the Imperial College of Science and Technology (chairman), Prof. A. V. Hill, Foulerton research professor of the Royal Society, Prof. P. M. S. Blackett, professor of physics at Birkbeck College, University of London, and Mr. H. E. Wimperis, Director of Scientific Research, Air Ministry. It will be seen that, with the exception of the last named, the committee's composition is nonofficial, and Sir Philip paid tribute to the public spirit which has induced these gentlemen to give their services. He also stated that while the body has been kept small to facilitate rapid progress, it is intended to invite other distinguished men of science to contribute to its investigations, and that its actual membership may be enlarged if and when it appears necessary. Prof. F. A. Lindemann, professor of experimental philosophy in the University of Oxford, has already been invited to assist, in view of the attention that he has given to the subject. It is intended to bring the committee's report before the Committee of Imperial Defence in due course.

\section{Radcliffe Telescope for University of London Observatory}

OXFORD, both University and the City, is witnessing now the first results of the legal decision upholding the rights of the Radcliffe Trustees to act in the best interests of Urania. This duty led them in the most obvious way possible to a happier clime, where clear skies with steady seeing occur with far more frequency than in Oxford. Quite soon the quaint but beautiful Radcliffe Observatory will cease to adorn the Woodstock Road, and Pretoria will glory in its opportunity to cherish the Radcliffe 72 -inch reflector now under construction at Newcastle-onTyne. Of late, the Trustees have been engaged in finding new domiciles for such instruments as are not required in South Africa, and to this end offered to the University of London as a free gift the most valuable of the telescopes. This is one of the finest examples of the skill of the late Sir Howard Grubb. It comprises a photographic refractor 24 inches in diameter and 270 inches in focal length, with a visual refractor 18 inches in diameter and 270 inches in focal length. The Senate of the University of London has accepted this magnificent gift for its observatory at Mill Hill, where for the last five years in a conspicuous building of attractive design an enthusiastic group has worked. This notable addition to the facilities of the Observatory is a fitting reward for much labour, in that it will provide further and extended opportunities for investigation which will no doubt be fully utilised. 